DOI: 10.17805/trudy.2016.1.6

\title{
АКТУАЛИЗАЦИЯ ТЕХНОЛОГИЧЕСКОГО КОМПОНЕНТА В СОВРЕМЕННОМ ЖУРНАЛИСТСКОМ ОБРАЗОВАНИИ
}

\author{
Ю. А. Головин \\ (Московский гуманитарный университет)
}

\begin{abstract}
Аннотация: В статье представляются проблемы современного российского журналистского образования, описывается практический опыт автора по подготовке журналистов в Институте МАСС МЕДИА Московского государственного университета культуры и искусств (ныне - МГИК), обоснована концепция подготовки журналистов в Московском гуманитарном университете.
\end{abstract}

Ключевые слова: журналист; подготовка журналистов; СМИ; российские СМИ; студенты-журналисты; медиаобразование

\section{ACTUALIZING THE TECHNOLOGICAL COMPONENT IN CONTEMPORARY EDUCATION IN JOURNALISM}

\author{
Yu. A. Golovin \\ (Moscow University for the Humanities)
}

Abstract: The article examines the problems of contemporary education in journalism in Russia, with a detailed look at the practical case of training journalists at the Institute of Mass Media, Moscow State University of Culture and Arts. The article concludes with providing a concept of a study program in journalism developed and implemented at Moscow University for the Humanities.

Keywords: journalist; education in journalism; mass media; mass media in Russia; journalism majors; media education

Состояние и перспективы российского профессионального медиаобразования давно и активно обсуждаются в академической среде, в прессе, в профессиональном журналистском сообществе (Шкондин, Демина, 2015: 460). Однако, в основном, речь идет о профессиональном журналистском образовании, проблемы профессиональной подготовки обходят молчанием. Между тем профессиональное образование и профессиональная подготовка - не тождественные понятия. Федеральный закон «Об образовании» указывает целью профессионального образование приобретение учащимися определенных компетенций, а целью профессиональной подготовки называет ускоренное приобретение обучающимися 
навыков, необходимых для выполнения определенной работы, группы работ, при этом оговаривается, что она не сопровождается повышением образовательного уровня обучающегося.

Исторически профессиональное образование журналистов начиналось именно с профессиональной подготовки: первой его формой было ученичество в редакциях. Когда возникло формальное профессиональное образование, то есть первые учебные заведения для газетчиков в системе начального, среднего и высшего профессионального образования, - оно также решало, в первую очередь, не образовательные, а профессиональноподготовительные задачи. Это было в первые годы советской власти, когда образованные люди неохотно шли в редакции, поэтому образовательные, общеобразовательные задачи начали все больше теснить профессиональную подготовку в учебных заведениях для журналистов. Особенно остро дефицит профессиональной подготовки стал ощущаться после исчезновения журналистских школ и техникумов, т. е. учреждений начального и среднего уровня. Таким образом, оказалось, что субъектов профессиональной подготовки журналистов в современной России нет вообще, а в высших учебных заведениях вопросам профессиональной подготовки, практической журналистике уделяется очень мало внимания. Не сталкивались ли вы с ситуацией, когда выпускник вуза восклицает со страхом: «Я ничего не умею делать в своей профессии!»?

Для осознания остроты проблемы полезно обратиться к зарубежному опыту, где существуют различные формы профессиональной подготовки журналистов. Наиболее наглядный пример - волонтариат в Германии и в некоторых других странах Евросоюза. В этом же ряду - обязательные длительные стажировки в редакциях как этап профессионального образования (без них документ о профессиональном образовании не выдается). Все это способы «формализации» профессиональной подготовки.

В СССР подобный опыт тоже был: в середине XX века после окончания 4-летнего курса университета студент проходил годичную практику в редакции. Но такая форма практики была признана неудачной. Конечно, причина не в ущербности стажировки или ненужности профессиональной подготовки, а в некоторой несовместимости ее с академически ориентированной моделью образования, которая использовалась для обучения журналистов. Стажировка и другие формы профессиональной подготовки более органичны для практико-ориентированной модели журналистского образования. Именно такую модель мы разрабатывали и пытались воплотить на практике в течение 14 лет в Московском государственном университете культуры, где в 2002 г. создали кафедру журналистики в социокультурной сфере, а затем и в созданный нами Институт MACC MEДИА, объединивший на тот момент практически все направления в ме- 
диаобразовании: журналистика, реклама, связи с общественностью, кино и телевидение, фототворчество и т. д. Впрочем, термина «медиаобразование» тогда еще не было и мы чуть ли не первыми ввели его в обиход.

Конечно, с самого начала мы опирались на опыт известных, наиболее продвинутых и востребованных образовательных журналистских структур в Москве. Это, прежде всего, факультет журналистики МГУ им. М.В.Ломоносова и Институт журналистики в РГГУ. Изучив их опыт работы, мы увидели, что классическое образование в МГУ предполагает мощный теоретический курс и глубокое филологическое образование: огромные потоки студентов-журналистов (более 300 человек), серьезные лекционные занятия и, если можно так выразиться, не очень активная индивидуальная, творческая работа студентов, недостаточная практическая работа с будущими журналистами, которые выходят в профессию. Во-многом, это была инерция. Еще работая журналистом, я сам не раз сталкивался с тем, что, когда в редакцию приходили выпускники журфака МГУ, их приходилось учить писать, то есть заново заниматься с ними практической журналистикой. Противоположным был опыт РГГУ: на телевизионной журналистике (единственной специализации в рамках специальности «Журналистика» на тот момент) была введена жесткая система практикоориентированной работы со студентами с 1-го курса. С самого начала в различных студиях и лабораториях их обучали премудростям профессии, но эти навыки они получали в ущерб теоретическим курсам, а филологическое образование вовсе оставалось «за скобками».

Мы тогда в своей практической деятельности пошли по пути соединения этих двух методик. Мы пришли к выводу, что для воспитания современного журналиста необходимо дать ему и качественное филологическое образование, и серьезные профессионально-практические навыки с первого дня учебы (Коханая, 2014: 80).

Конечно, задача была непростая, но нам помогло руководство МГУКИ. Решением ректората практически сразу нам была передана общеуниверситетская газета «Аудитория». Каждый наш студент 1-го курса объявлялся корреспондентом газеты «Аудитория». Таким образом, мы распределяли журналистов по тематическим направлениям, благо Университет культуры практически являлся некоей моделью мощного культурологического пространства России со всеми его направлениями социально-культурного развития. Например, если мы студента «прикомандировывали» к театрально-режиссерскому факультету - он становился частью театрального коллектива: наблюдал за процессом создания спектакля, был на премьере, пытался писать рецензию на этот спектакль и т. д. То же самое происходило в Институте музыки, в Академии танца или любом другом учебном подразделении университета. И только по- 
сле такой практики мы выводили наших студентов в профессиональные СМИ. Но мы понимали, что если студент будет практиковаться только у себя в вузе, из него мало, что получится. К тому же, по Госстандарту и учебному плану «Журналистики» на все виды практики (с 1-го по 5-й курс ежегодно) отводись 26 недель. Это практически тот самый год стажировки студента-выпускника, что был в советские времена. Но обеспечивать этот последовательно-поступательный процесс практики каждого студента, развивая его индивидуальные творческие задатки и способности, на протяжении всех лет было непросто.

Педагогам, отвечающим за практику, хорошо известно, что производственная и преддипломная практика (всего 21 неделя) имеют свою специфику: редакции газет, журналов, телевидения и радио, даже самые крупные, могут одновременно принимать не более 2-4 студентов ввиду занятости журналистов и жесткого ритма их профессиональной деятельности, а иногда и отсутствия производственных площадей. Кроме того, редакции предъявляют свои требования к тому, какие профессиональные качества уже должен иметь практикант до прихода на практику. Поэтому устроить в профессиональные редакции десятки, а то и сотни студентов одновременно даже в условиях Москвы практически невозможно.

Данная проблема очевидна и для самих студентов, правда, несколько с другой стороны. Им предстоит не только максимально раскрыть свой творческий потенциал, но и стать конкурентоспособными: демонстрировать лидерские качества, способность быть первыми и лучшими в своем «формате». Хотя современные студенты с ярко выраженной потребительской ориентацией не всегда понимают, что их межличностная профессионально-творческая конкуренция, хоть и в тепличных условиях, уже началась (Ковалева, 2015: 349). В этих ножницах вопрос организации практики ежегодно становится сложнейшей проблемой практически для любой кафедры журналистики.

Поэтому естественным решением в сложившихся условиях нам показалось внедрение практической журналистики в учебный процесс. В частности мы решили, что занятия по некоторым дисциплинам, таким как «Основы творческой деятельности журналиста», «Журналистское мастерство (работа в творческих студиях)», должны проходить непосредственно в редакциях, там, куда придет практикант, а затем выпускник. Мы заключили договоры о сотрудничестве с газетами и телеканалами, которые близки нам по профилю, в частности, с «Литературной газетой», «Исторической газетой», газетой «Культура», телеканалом ТВЦ, в частности с популярной в те годы программой «Лицом к городу», где каждый из студентов 4-го курса фактически делал как минимум один выпуск от начала до конца (написание сюжета, съемка, монтаж и т. д.). Вопрос оплаты 
мы решали путем приглашения на работу журналистов-практиков из тех самых редакций. Благо и Министерство культуры и прежнее руководство университета шли нам на встречу. Таким образом, студенты набирались практического опыта в рамках учебного процесса (Кощиенко, 2014: 8).

Но, с увеличением потока студентов мы поняли, что полностью эту проблему, таким образом, не решить (Смеюха, 2015: 164). Развивая идею практической подготовки журналистов, мы в 2005 году создали в Институте МАСС МЕДИА Научно-производственный Центр медиа-технологий, по сути - «студенческий медиа-холдинг». В него вошли учебная телестудия «Акценты»; газеты «Аудитория» и «Вестник МГУКИ», последняя стала официальным общеуниверситетским изданием; студенческий прессцентр, ставший за короткое время общеуниверситетской структурой по связям с общественностью; литературно-художественный, научнопросветительский альманах «Зеркало» и литературное объединение при нем; дирекция студенческих фестивалей, куда входили Российский студенческий фестиваль социальной рекламы (РСФСР), Общероссийский фестиваль молодежной журналистики «Пингвины пера», Международный фестиваль документального кино «Пятерочка».

Именно здесь, в Центре медиа-технологий, в рамках самостоятельной работы под руководством профессионалов наши студенты получали практические навыки, овладевали профессиональным мастерством в журналистике, рекламе, PR-e, киноискусстве. Занятия в Центре проходили как в рамках учебного расписания, так и после окончания обязательных учебных занятий. Именно здесь начал проявляться ранее не исследованный феномен самоконкуренции, когда журналист стремится к новым победам, чуть ли не каждый день поднимая свою профессиональную «планку». Результат не замедлил сказаться. Уже в первый год существования Центра в различных СМИ, усилиями студентов и преподавателей нашей структуры появилось более 300 положительных публикаций об Университете. Наши студенты стали желанными практикантами в известнейших редакциях и студиях, потому как реально могли помочь в подготовке материалов и программ (Головин, Коханая, 2015: 366). Особенно в период отпусков. А в 2013 г. на празднование десятилетия кафедры, подводя итоги, мы выяснили, что 95\% наших выпускников работают по специальности, многие в популярных изданиях, известных радиостанциях, на федеральных каналах, некоторые - Андрей Сенцов, Юрий Столяров, Никита Васильев, Алексей Головин - стали ведущими специалистами своих медиаструктур.

Главные составляющие нашего опыта: объединение в один мощный институт (факультет) всех направлений подготовки, связанных с формированием и функционированием медиапространства; привлечение к ме- 
диаобразованию работодалей, передав им часть практических дисциплин и вынеся эти занятия непосредственно в сами медиаструктуры; создание на базе института (факультета) студенческого Центра медиа-технологий (медиа-холдинга), в котором решались бы не только образовательные, но и воспитательные, мировоззренческие, а в некоторых случаях и коммерческие задачи. Студенческий медиа-холдинг, в конечном итоге должен стать общеуниверситетской структурой, работающей на его имидж в медиапространстве.

Особенно актуальной эта проблема стала сегодня, когда Министерство образования России усилиями своих чиновников под надуманным предлогом вхождения в мировой образовательный процесс (естественно, никуда мы не вошли, да и не могли войти, потому, как никому мы там не были нужны) навязали нам искусственную, так называемую «Болонскую» систему образования. Сейчас уже понятно, что никакой такой «Болонской» системы и в помине нет и никогда не было, и уж точно никто в мире в том виде, в котором это делаем мы ее не реализует. Просто нашлись ушлые ребята от образования, которые под это дело растащили по карманам ни один миллиард бюджетных рублей. И, конечно же, есть активно развивающийся мировой процесс капитализации образования, то есть все более жесткого разделения на элиту и быдло, что для Росси не только неприемлемо, но и смертельно опасно (Ильинский, 2014: 11; см. также: Ильинский, 2013; Ковалева, 2013). Тем не менее, несмотря на все сложности, с практикующих педагогов не снимал ответственности за профессиональную подготовку специалистов, за воспитание патриотов России (Бородай, 2015: 18).

А потому сегодня, когда нас заставляют втиснуться в пресловутые четыре года, обозвав эту профанацию образования заграничным словом «бакалавриат», создание студенческих медиаструктур, где студенты могли бы получать профессиональные навыки, оттачивать мастерство и учиться работать в коллективе становится по настоящему актуальным. Именно таким путем мы пошли год назад в Московском гуманитарном университете (МосГУ). В мае 2014 г. здесь была открыта кафедра журналистики, в августе мы осуществили первый набор, уже с сентября весь курс по дисциплине «Журналистское мастерство» занимался в офисе «Литературной газеты», под руководством доцента нашей кафедры, первого заместителя главного редактора «ЛГ» Л. В. Колпакова, в декабре того же года мы создали студенческий пресс-центр, в январе 2015 г. исключительно силами первокурсников, выпустили первый номер студенческой газеты «Пробы пера». В мае 2015 г. наша команда участвовала в Российском фестивале молодежной журналистики «Пингвины пера».

В начале 2015/2016 учебного года, совместно с факультетом рекламы мы разработали план развития кафедры журналистики, главным пунктом 52 
которого является как раз создание студенческого центра медиатехнологий.

\section{СПИСОК ЛИТЕРАТУРЫ}

Бородай, А. Д. (2015) Художественная интеллигенция в современной России: потенциал влияния на общество // Научные труды Московского гуманитарного университета. № 1 (169). С. 15-29.

Головин, Ю. А., Коханая, О. Е. (2015) Востребованные профессии в сфере масс-медиа: методика быстрого прогнозирования // Вестник Челябинского государственного университета. № 5 (360). С. 365-371.

Ильинский, И. М. (2013) Образовательные технологии; соотношение традиций и новаторства // Знание. Понимание. Умение. № 3. С. 3-7.

Ильинский, И. М. (2014) Российские вузы на переломном этапе // Знание. Понимание. Умение. № 3. С. 5-17.

Ковалева, А. И. (2013) Методическая школа вуза // Знание. Понимание. Умение. № 2. С. 307-309.

Ковалева, А. И. (2015) Тезаурусная концепция социализации // Знание. Понимание. Умение. № 3. С. 348-353.

Коханая, О. Е. (2014) Современная медиасреда и образовательные стратегии воспитания // Труды Ростовского государственного университета путей сообщения. № 1. С. 79-82.

Кощиенко, И. В. (2014) Педагогический менеджмент как условие становления и развития современной системы образования //

Высшее образование для XXI века: XI Международная научная конференция. Москва, 27-29 ноября 2014 г. : Доклады и материалы. Секция 8. Педагогика и образование. Ч. 1. Педагогический менеджмент / отв. ред. Н. И. Федотова. М. : Изд-во Моск. гуманит. ун-та. 69 с. С. 6-9.

Смеюха, В. В. (2015) Особенности подготовки бакалавров по направлению «Реклама и связи с общественностью» // Труды Ростовского государственного университета путей сообщения. №1 (30). С. 160-165.

Шкондин М. В., Демина И. Н. (2015) Медиасистема: аспекты синергетического анализа // Вопросы теории и практики журналистики. Т. 4. № 4. С. $456-461$.

Дата поступления: 15.11.2015 2.

Головин Юрий Алексеевич - доктор культурологии, профессор, заведующий кафедрой журналистики Московского гуманитарного университета. Адрес: 111395, Россия, г. Москва, ул. Юности, д. 5. Тел.: +7 (499) 374-60-91. Эл. адрес: yagolovin51@yandex.ru 
Golovin Yurii Alekseevich, Doctor of Culturology, Professor and Chair, Department of Journalism, Moscow University for the Humanities. Postal address: 5 Yunosti St., 111395 Moscow, Russian Federation. Tel.: +7 (499) 37460-91.E-mail: yagolovin51@yandex.ru 